\title{
Growth Effects of Capital Inflows and Investment in Nigeria
}

\author{
${ }^{*}$ Fredrick Ikpesu
}

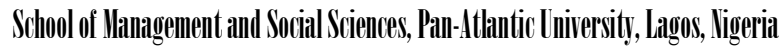

\begin{abstract}
The aim of this study was to ascertain the growth effects of capital inflows using investment as a transmission channel between the periods 1981 to 2016 in Nigeria. The study employed the least square regression method to analyse the data. The outcome of the research indicates that capital inflows have a positive and significant effect on the growth of the Nigeria economy. This imply that foreign capital inflows have contributed to the economic growth of the country. Furthermore, the research output also showed that domestic investment has a positive and significant effect on Nigerian economic growth. From the findings of the study, it is concluded that capital inflow and domestic investment has positively contributed to the growth of Nigeria economy. The findings of this study posed significant policy direction. Firstly, the study emphasized the need for government and policy-makers to attract more inflow of foreign capital into the country but the detrimental effect of huge capital inflow into an economy should also be considered. Secondly, the government should determine the optimal capital inflow that would propel investment and growth in the country. Thirdly, the government should strengthen the macroeconomic fundamentals by deepening structural reforms so as to ensure sustainable capital inflows into the country. Finally, the government should create an enabling environment by providing the needed infrastructural facilities in a bid to attract foreign investors and encouraging domestic investment in the country.

Keywords: Capital inflow, investment, growth, augmented solow growth model, Nigeria

JEL:F21, P33
\end{abstract}

The role of foreign capital in promoting and enhancing growth has been established in the extant literature. Several strands of literature have shown that through capital inflow developing economies can supplement their domestic capital by providing the needed developmental project that will aid growth and eradicate poverty among the populace. Majority of the developing economies face savings and foreign exchange constraints and relie on the inflow of foreign capital in closing the gap. The theoretical underpinning for the justification of foreign capital is the two-gap model (Nwokoma, 2013) which was developed by Chenery and Strout (1966). According to this model, foreign capital is required in closing the savings and investment gap and the foreign exchange gap faced by developing

Manuscript received October 19, 2018; revised February 15, 2019; accepted March 2, 2019. @ The Author(s); CC BY-NC; Licensee IJMESS

*Corresponding author: fikpesu@pau.edu.ng 
economies.

Capital inflow is most desirable having played a great role in less developed economies where domestic resource is insufficient (Nwokoma, 2013) and in the development of industrialized economies (Obadan, 2004). Similarly, research findings by Reinhart (2005) show that through capital inflow, recipient economies can finance developmental projects that will ensure growth and eradicate poverty enhancing donor economies welfare since capital outflow smoothen the consumption pattern of the donor countries which thus aids them in achieving higher consumption in the long-run.

However, some studies questioned the exact role of capital inflow in promoting the growth of developing economies (Akinlo, 2004; Ali, 2014; Rajan and Subramanian, 2005; Sakyi, 2011). In addition, studies have shown that huge capital inflow can cause a problem in the management of the economy (Obadan, 2013; Okojie, 2013). Research findings by Obadan (2013) revealed that huge capital inflow has been the major cause of financial crisis. For instance, the 1994-1995 Mexican financial crisis, the 1997-1998 East Asian and Russian crisis, the Turkey crisis in 2000-2001 and the 2001-2002 Argentina crisis were all caused by the huge amount of capital inflow into their economies. In addition, high capital inflow into an economy can cause overheating of the macroeconomic, inflationary pressure and exchange rate appreciation which affect the competitiveness of the export of an economy in the international market (Dagnachew, 2014; Nwokoma, 2013; Obadan, 2013; Obiechina and Uzodinma, 2013; Okojie, 2013).

In the literature, majority of the studies both at the country level and across countries focused on the effect of capital inflows on growth (Dagnachew, 2014; Gomanee et al., 2005; Odhiambo, 2011; Ogbechie and Anetor, 2016; Osinubi and Amaghionyeodiwe, 2010; Sethi, 2013; Soto, 2000). The literature, however, remains salient on the link between capital inflow, investment, and growth despite the increasing significance of capital inflows, and investment in the economic prosperity of nations. Hence, the motivation for the study. Another motivation for the study is the quest for foreign capital in the country because of the wide gap that exists between the capital inflow required and the one mobilized by the country for investment purpose. Hence, the basic research question this study 


\section{Ikpesu}

attempt to address is to investigate the growth effect of capital inflows in Nigeria using investment as a transmission channel.

Furthermore, the study provides evidence on the existence and nature of the dynamic relationship between capital inflows and growth by including investment as the specific channel through which capital inflow may affect growth. The inclusion of the investment in the model is motivated by the fact that capital inflows alone would not be adequate in stimulating growth. Hence, the inclusion of investment as transmission channels in the analysis enhances the influence of capital inflows on Nigerian growth. This study explores the aggregate impact of capital inflows on growth using investment as a transmission channel within the augmented Solow growth model employing data spanning from 1981 to 2016

The contribution of the study to the empirical literature is that, the study provides some empirical evidence about aggregate capital inflows to Nigeria that can can spur growth using investment as a transmission channel. The research outcome of the study indicates that capital inflows have a positive and statistically significant impact on Nigeria growth as do domestic investment. The findings from the study suggest that capital inflows and domestic investment play a key role in the economic growth of the country.

The remainder of this paper is organized as follows: section two presents the review of theory and empirical literature while section three presents the econometric issues and model. Section four presents the empirical result and discussion. Section five presents the conclusion and policy implications of the study while section six focus on the limitation of the study.

\section{LITERATURE REVIEW}

According to the two-gap model developed by Chenery and Strout (1966), developing economies are faced with savings and foreign exchange gap which prevents them in embarking on developmental projects that will enhance productivity and promote growth. The savings gap is the gap between savings and investment while the foreign exchange gap is the gap between export and import. The th- 
International Journal of Management, Economics and Social Sciences

eory advocates the need for the inflow of foreign capital in relieving the savings and foreign exchange constraint. In addition, the theory posits that with the inflow of foreign capital, developing economies can attain the target growth needed to ensure sustainable development. Furthermore, according to the neoclassical growth theory, the inflow of foreign capital enables developing economies to acquire the needed technology that will enhance productivity, stimulate growth and ensure sustainable development (Adegbite and Adetiloye, 2013; Obadan, 2013; Reinhart, 2005; Tahir et al., 2015).

However, empirical studies on the effect of capital inflows on growth in the literature have shown a mixed result. A possible reason for this is that capital inflows may lead to an appreciation of exchange rate which thus affects the competitiveness of the export of a country and this may have a negative impact on the growth of such economies. Several empirical evidences have shown that capital inflows influence growth positively (Bailliu, 2000; Ekwe and Inyiama, 2014; Gomanee et al., 2005; Odhiambo, 2011; Ogbechie and Anetor, 2016; Osinubi and Amaghionyeodiwe, 2010; Sethi, 2013; Soto, 2000; Udoidem and Udofot, 2014).

In addition, Ajayi and Oke (2012) findings showed that capital inflow has a negative effect on growth. Ayadi and Ayadi (2008) while comparing the effect of capital inflow on growth between Nigeria and South Africa revealed that capital inflow promotes growth in Nigeria whereas, in South Africa, capital inflow retards growth. Also, following studies (Akinlo, 2004; Ali, 2014; Rajan and Subramanian, 2005; Sakyi, 2011) revealed that capital inflow retards growth.

Furthermore, empirical studies in the literature have also shown the link between domestic investment and growth. Bakari (2017) using a vector error correction model (VECM) approach concluded that in the long-run, domestic investment affects growth negatively, while in the short-run, domestic investment affects growth positively in Algeria. Adopting a VECM technique Bakari (2017) revealed that in Malaysia, there is no link between domestic investment and growth in the short-run, whereas in the long-run, domestic investment affects growth positively. Similarly, Chidoko and Sachirarwe (2015) revealed that in Zimbabwe, domestic investment affects growth positively. Ullah et al. (2014) concluded that domestic investment and economic growth are co-integrated in Pakistan. T- 


\section{Ikpesu}

heir result further revealed that domestic investment Granger cause economic growth. Mndeme (2015) documented that in Tanzania, the relationship between domestic investment and growth is evident in long-run.

Lean and Tan (2011) showed that domestic investment affects growth in Malaysia in the long-run. Ilegbinosa et al. (2015) found that private investment affects growth in Nigeria positively. Iya and Aminu (2015) also concluded in their research findings that domestic investment has positively impacted the growth of Nigerian economy. Emeka et al. (2017) findings revealed that a long-run relationship exists between domestic investment and growth. In addition, their research outcome further showed that domestic investment Granger cause growth in Nigeria. In the same line, Omoregie and Ikpesu (2017) concluded that domestic investment affects growth positively in Nigeria.

From the above review of the literature, while scholars agree on the positive role of domestic investment on growth, there seems to be no consensus on the role of capital inflow on growth. This study fills the gap in the literature by investigating the growth effect of capital inflows in Nigeria using investment as a transmission channel. Also, the study employs the use of aggregate capital inflow (private and public flow) unlike previous studies. See Appendix-IV for literature review summary.

\section{METHODOLOGY}

In estimating the growth effect of capital inflow and investment, the study adopts the augmented solow growth model which was developed by Mankiw et al. (1992). The reasons for using the specification model is because of the aim of the study and also in the model, there is an inclusion of human capital which promotes growth and productivity of labor.

Following theoretical postulations, review of extant literature, similar studies and taking into consideration the variables of interest (capital inflow, and domestic investment), and control variables, the study empirical model is expressed by adopting a standard growth equation:

$$
Y \mathrm{it}=\alpha_{i}+\beta C A P I t+\partial I N V t+\theta X t+\varepsilon t
$$

Where Yit is GDP per capita at time $t, \alpha i$ shows the coefficient. CAPI is capital inflow (comprising fo- 
reign borrowing, portfolio investment, workers remittance, official development assistance, and foreign direct investment) at time $t$, INVit is domestic investment at time $t, \mathrm{X}$ is the vector of control variables (life expectancy at birth (LE), population growth (POPGR), secondary school enrolment (EDU), real exchange rate (REXR), inflation (INF) and money supply (M2). The life expectancy at birth, secondary school enrolment, and population growth was included in the model to capture the impact of human capital while real exchange rate, money supply, and inflation were used as a proxy for macroeconomic stability. The $\varepsilon t$ is the error term while $\beta, \delta$ and $\theta$ are the parameter coefficients to be estimated in the study.

\section{-Data and Variables Definition}

Annual data covering the period 1981 to 2016 were employed in this study. The covering period in the study was based on the availability of data. The data were sourced from World Bank Development Indicator and Central Bank of Nigeria (CBN) Statistical Bulletin. The dependent variable used in the study is GDP per capita (PCY) while the independent variable is the domestic investment (INV). In line with previous studies, a set of control variables, usually employed in the growth equation, were also included in the study model. Table 1 (see Appendix-I) shows the variables, definitions, and sources of all the variables used in the study.

\section{RESULTS}

The study first examined the stationarity property of the variables prior to investigating the growth effects of capital inflow and investment. Results (see Table 2, Appendix-II) revealed that all the variables are stationary at level. This implies that the variables do not have a unit root. Hence, the null hypothesis of the presence of a unit root is rejected.

Table 3 (Appendix-III) shows the result of the least square estimate. The result revealed that capital inflow has a positive and significant effect on economic growth. This implies that capital inflow has contributed positively to the growth of Nigerian economy. The research finding supports the research work of Ekwe and Inyiama (2014), Ogbechie and Anetor (2016), Saibu (2014) and Udoidem and Udo- 


\section{Ikpesu}

fot (2014). The results further revealed that domestic investment has a positive and significant effect on growth. This suggests that in the country, domestic investment influenced the growth of Nigerian economy. This corroborates the findings of Bakari (2017), lya and Aminu (2015), Omoregie and Ikpesu (2017) and Ullah et al. (2014).

The results in Table 3 also showed that real exchange rate has a positive and significant effect on growth. This implies that an appreciation in the real exchange rate will lead to the growth of the Nigerian economy. In addition, the result also revealed that population growth affects economics growth positively while life expectancy at birth and secondary school enrolment affect economics growth negatively. Furthermore, the money supply was shown to affect economic growth positively. The adjusted $R$-square of 0.998 or 99 percent indicates that the explanatory variables were robust in explaining the variation in economic growth. It also shows that the model has a good fit. The significance of the $f$-statistic showed that the whole regression model was significant. The DurbinWatson result revealed that the model was free from serial correlation.

The presence of serial correlation was further tested by carrying out the Breusch-Godfrey serial correlation Lagrange Multiplier test and the result revealed that the model was free from serial correlation. Furthermore, the heteroscedasticity test was also carried out using the Breusch-PaganGodfrey test. The result of the test indicates that the model was free from heteroscedasticity. Figure 1 shows the stability test (see Appendix-V) which was carried out using Cumulative Sum (CUSUM) test and CUSUM of square test. Both test statistics (the blue line) fall within the lower and upper limits (red dotted lines) indicating that the estimated coefficient is reliable and stable for analysis purpose.

\section{CONCLUSION AND POLICY IMPLICATIONS}

The study investigates the growth effect of capital inflow using investment as a transmission channel between the periods 1981 to 2016 in Nigeria. Data employed in the study were sourced from the world development indicators and the Central Bank of Nigeria (CBN) statistical bulletin. The dependent variable of the study is economic growth which is measured as GDP per capita while the independent variables are capital inflow (private flows and public flows) and investment. In line with previous 
empirical studies, a list of control variables (inflation rate, real effective exchange rate, money supply, population growth rate, life expectancy at birth and secondary school enrolment) was included in the study.

The empirical findings from the study reveal that the variables are co-integrated i.e. the variables have a long-run relationship. The outcome of the research further shows that capital inflow and domestic investment has a positive and significant effect on Nigerian growth. Hence, the study concludes that capital inflow and domestic investment has positively contributed to the growth of Nigerian economy.

The findings of this study pose significant policy directions. Firstly, the study emphasizes the need for government and policy-makers to attract more inflow of foreign capital into the country but taking into consideration the detrimental effect of huge capital inflow into the economy. Secondly, the government should determine the optimal capital inflows that would propel investment and growth in the country. Thirdly, the government should strengthen the macroeconomic fundamentals by deepening structural reforms so as to ensure sustainable capital inflows into the country. Fourthly, the government should create an enabling environment by providing needed infrastructural facilities in a bid to attract foreign investors and encouraging domestic investment in the country.

Finally, according to the two-gap model, developing economies require capital inflows so as to close the savings and foreign gap. Also, the neoclassical growth theory lends credence to the significance of capital inflows in enabling developing economies in acquiring the needed technology that will enhance productivity and promote growth. The result from the study is in line with theory, however, the country should be cautious in allowing huge capital inflows into the economy because it can cause detrimental effects in the management of the economy based on past experience of countries who allowed huge capital inflow into their economy as revealed in the literature.

\section{LIMITATIONS AND FUTURE DIRECTIONS}

The study uses aggregate capital inflow (public and private inflow) instead of its components. Future 


\section{Ikpesu}

studies can disaggregate the capital inflow. Also, the study sample was a single country, future

studies can focus on the growth effect of capital inflow and investment using a cross-country data.

The dynamic interaction among growth, capital inflow, and investment can also be investigated.

\section{REFERENCES}

Adegbite, E.O. \& Adetiloye, K. A. (2013). Financial globalization and domestic investment in developing countries: evidence from Nigeria. Mediterranean Journal of Social Sciences, 6(4): 213-221.

Ajayi, L.B. \& Oke, M.O. (2012). Effect of external debt on economic growth and development of Nigeria. International Journal of Business and Social Science, 3(2): 297-304.

Akinlo, A.E. (2004). Foreign Direct Investment and Growth in Nigeria an Empirical Investigation. Journal of Policy Modeling, 26, 627-639.

Ali, S. (2014). Foreign capital flows and economic growth in Pakistan: An empirical analysis. World Applied Sciences Journal, 29(2): 193-201.

Ayadi, F.S., \& Ayadi, F.O. (2008). The impact of external debt on economic growth: A comparative study of Nigeria and South Africa. Journal of Sustainable Development in Africa, 10(3): 234-264.

Bailliu, J. (2000). Private capital flows, financial development, and economic growth in developing countries, Bank of Canada Working Paper No. 2000-15 (Ottawa: Bank of Canada). Bakari, S. (2017). The Impact of domestic investment on economic growth: New policy analysis from Algeria. Bulletin of Economic Theory and Analysis, 3(1): 35-51.

Bakari, S. (2017). The impact of domestic investment on economic growth: New evidence from Malaysia. Journal of Smart Economic Growth, 2(2): 105-121.

Chenery, H.B., \& Strout, A. M. (1966). Foreign assistance and economic development. The American Economic Review, 56(4): $679-733$

Chidoko, C. \& Sachirarwe, I. (2015). An analysis of the Impact of investment on economic growth in Zimbabwe. Review of Knowledge Economy, 2(2): 93-98

Dagnachew, T.W. (2014). Capital inflows and real effective exchange rate in Zambia: Investigating dutch disease using cointegrated VAR approach (Doctoral dissertation, Master Thesis (Faculty of social science, University of Copenhagen).

Ekwe, M.C, \& Inyiama, O.I. (2014). Foreign capital flows and growth of the Nigeria economy: An empirical review. International Journal of Economics and Finance, 6(4):103-109.

Emeka, A., Idenyi, O.S. \& Nweze, N.P. (2017). Domestic investment, capital formation and economic growth in NIGERIA. International Journal in Research and Social Science, 7(2): 41-65.

Gomanee, K., Girma, S. \& Morrissey, O. (2005). Aid and growth in Sub-Saharan Africa: accounting for transmission mechanisms. Journal of International Development, 17(8): 1055-1075.

Ilegbinosa, I.A., Micheal, A. \& Watson, S.I. (2015). Domestic investment and economic growth in Nigeria From 1970-2013: An econometric analysis. Canadian Social Science, 11(6): 70-79.

lya, I.B. \& Aminu, U. (2015). An investigation into the impact of domestic investment and foreign direct investment on economic growth in Nigeria. International Journal of Humanities Social Sciences and Education, 2(7): 40-50.

Lean, H.H., \& Tan, B.W. (2011). Linkages between foreign direct investment, domestic investment and economic growth in Malaysia. Journal of Economic Cooperation and Development, 32(4): 75-95.

Mankiw, N.G., Romer, D. \& Weil, D. N. (1992). A contribution to the empirics of economic growth. The Quarterly Journal of Economics, 107(2): 407-437.

Mndeme, R.K. (2015). Domestic investment, savings and economic growth in Tanzania: A Dynamic Multivariate Analysis. Journal of Economics and Sustainable Development, 6(14): 56-68.

Nwokoma, N.I. (2013). Capital flows and macroeconomic stability: theoretical and conceptual considerations. Central Bank of Nigeria, 51(4): 1-25.

Obadan, M.I. (2004). Foreign Capital Flows and External Debt: Perspectives on Nigeria and the LCDs Group. Broadway Press.

Obadan, M.I. (2013). Coping with capital flow volatility: policy consideration for Nigeria. Central Bank of Nigeria, 51(4): 177195.

Obiechina, M.E. \& Uzodinma U.E. (2013). Economic growth, capital flows, foreign exchange rate, export and trade openness in Nigeria. International journal of Economics and Management Sciences, 2(9):1-13.

Odhiambo, N. M. (2011). Financial deepening, capital inflows and economic growth nexus in Tanzania: A multivariate model. Journal of Social Sciences, 28(1): 65-71.

Ogbechie, C. \& Anetor, F. (2016). Dynamic interaction between capital flows, exchange rates and growth: Evidence From Nigeria. Journal of Economics and Trade, 1(1): 11-27.

Okojie, C.E. (2013). Policy space for capital controls and macroeconomic stability: Lessons from emerging economies. Central Bank of Nigeria, 51(4): 145-175.

Omoregie, O.K. \& Ikpesu, F. (2017). Dynamic interaction between savings, investment and economic growth in Nigeria: A Vector autoregressive (VAR) approach. The Journal of Developing Areas, 51 (3): 267-280.

Osinubi, T.S. \& Amaghionyeodiwe, L.A. (2010). Foreign private investment and economic growth in Nigeria. Review of Economics and Business Studies, 3(1):105-127. 
International Journal of Management, Economics and Social Sciences

Rajan, R.G. \& Subramanian, A. (2005). What undermines aid's impact on growth? (No. w11657). National Bureau of Economic Research.

Reinhart, M. (2005). Some perspective on capital flows to emerging market economies. NBER Reporter. Research Summary.

Saibu, O. M. (2014). Capital Inflow and Economic Growth Nexus in Nigeria: The Role of Trade Openness. Acta Universitatis Danubius, 10(6): 98-112.

Sakyi, D. (2011). Trade openness, foreign aid and economic growth in post-liberalisation Ghana: An application of ARDL bounds test. Journal of Economics and International Finance, 3(3):146-156.

Sethi, N. (2013). Causal relationship between foreign capital inflows and economic growth: Empirical evidence from India. International Journal of Economics, Finance and Management

Soto, M. (2000). Capital flows and growth in developing countries: Recent empirical evidence. OECD Development Centre, Technical Papers No. 160.

Tahir, M., Khan, I. \& Shah, A.M. (2015). Foreign remittances, foreign direct investment, foreign imports and economic growth in Pakistan: a time series analysis. Arab Economic and Business Journal, 10(2): 82-89.

Udoidem, J.O. \& Udofot, P. (2014). Foreign capital inflows and entrepreneurship in Nigeria: The implication for economic growth and development. International Journal of Finance and Accounting, 3(3): 174-184.

Ullah, I., Shah, M. \& Khan, F.U. (2014). Domestic investment, foreign direct investment, and economic growth nexus: A case of Pakistan. Economics Research International. Article ID 592719, 1-2. 


\begin{tabular}{|c|c|c|}
\hline Variable & Definition & Source \\
\hline \multicolumn{3}{|c|}{ Dependent variable } \\
\hline PCY & GDP per Capita & World Development Indicator \\
\hline \multicolumn{3}{|c|}{ Independent variable } \\
\hline CAPI & Capital inflow & $\begin{array}{l}\text { World Development Indicator, CBN } \\
\text { statistical bulletin }\end{array}$ \\
\hline INV & Domestic Investment & World Development Indicator \\
\hline \multicolumn{3}{|c|}{$\begin{array}{l}\text { Macroeconomic stability } \\
\text { variables }\end{array}$} \\
\hline $\mathrm{INF}$ & $\begin{array}{l}\text { Inflation which is rate of change in } \\
\text { price level }\end{array}$ & World Development Indicator \\
\hline REXR & Real exchange rate & World Development Indicator \\
\hline M2 & Money supply & CBN statistical bulletin \\
\hline \multicolumn{3}{|c|}{$\begin{array}{l}\text { Human and physical } \\
\text { capital variable }\end{array}$} \\
\hline POPGR & Population growth rate & World Development Indicator \\
\hline LE & Life expectancy at birth & World Development Indicator \\
\hline EDU & Secondary school enrollment & World Development Indicator \\
\hline
\end{tabular}

Table 1. Variable, Definition and Source 
Appendix-II

\begin{tabular}{lcc}
\hline \multicolumn{3}{c}{ Group Unit Root Test: Summary } \\
\hline \multicolumn{1}{c}{ Level } \\
\hline Series: LOG(GDPPC), LOG(CAPI), LOG(INV), REXR, INF, LOG (M2), POPGR, LE, EDU, \\
\hline Method & Statistic & Prob. \\
Levin, Lin \& Chu $t^{*}$ & -7.05133 & $0.0000^{* * *}$ \\
Im, Pesaran and Shin W-stat & -2.70441 & $0.0034^{* * *}$ \\
ADF - Fisher Chi-square & 51.1536 & $0.0001^{* * *}$ \\
PP - Fisher Chi-square & 17.3344 & 0.5002 \\
\hline
\end{tabular}

$* * *$, and $* *$ shows the rejection of the null hypothesis of the existence of a unit root at $1 \%$, and $5 \%$

Table 2. Stationarity Test 


\section{Ikpesu}

Appendix-III

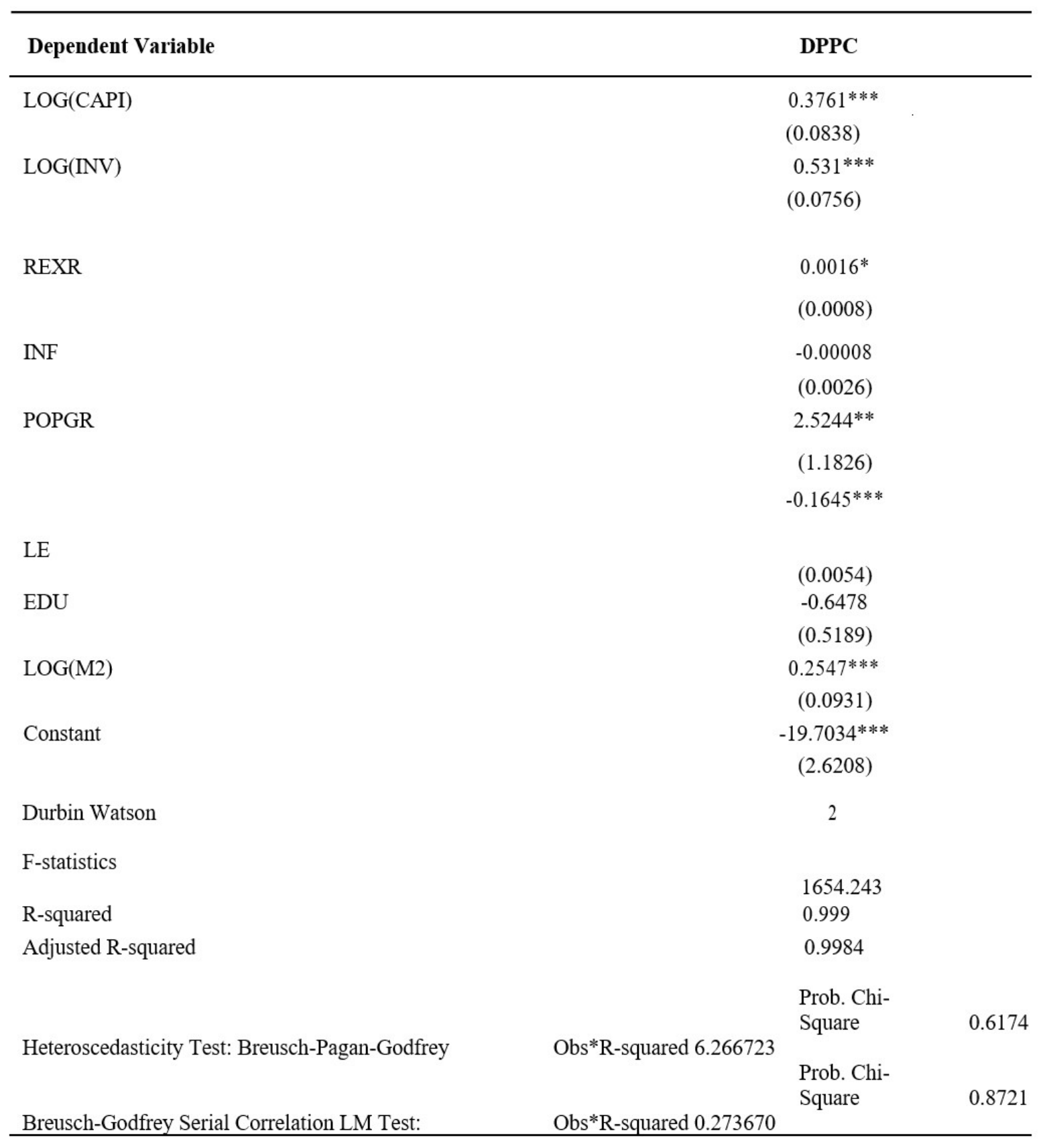

Note: $* * * * *$ indicates significance at $1 \%$, and $5 \%$ level respectively. The figure in bracket represent standard errors

Table 3. Least Square Regression Estimate 


\begin{tabular}{|c|c|c|c|c|}
\hline $\begin{array}{c}\text { Author(S) / } \\
\text { Year }\end{array}$ & Country & $\begin{array}{l}\text { Period } \\
\text { Covered }\end{array}$ & $\begin{array}{l}\text { Estimation } \\
\text { Technique }\end{array}$ & Main Findings \\
\hline $\begin{array}{l}\text { Gomanee et al. } \\
\text { (2002) }\end{array}$ & $\begin{array}{l}\text { Sub-Saharan } \\
\text { Africa (SSA) } \\
\text { economies }\end{array}$ & 1970-1997 & Pooled OLS & $\begin{array}{l}\text { Aid positively affects economic } \\
\text { growth in SSA. }\end{array}$ \\
\hline $\begin{array}{c}\text { Ogbechie \& } \\
\text { Anetor (2016) }\end{array}$ & Nigeria & 1986-2014 & VAR & $\begin{array}{l}\text { Capital inflows react positively } \\
\text { to economic growth in Nigeria. }\end{array}$ \\
\hline Bailliu (2000) & $\begin{array}{c}\text { Forty } \\
\text { developing } \\
\text { economies } \\
\end{array}$ & 1975-1995 & $\begin{array}{c}\text { Generalized Method } \\
\text { of Moments } \\
\text { (GMM) } \\
\end{array}$ & $\begin{array}{l}\text { Capital inflows foster higher } \\
\text { economic growth. }\end{array}$ \\
\hline $\begin{array}{c}\text { Udoidem \& } \\
\text { Udofot (2014) }\end{array}$ & Nigeria & $1980-2008$ & $\begin{array}{c}\text { Descriptive and } \\
\text { Correlation }\end{array}$ & $\begin{array}{l}\text { Capital inflows aid the activities } \\
\text { of entrepreneurs and this, in } \\
\text { turn, positively impact growth } \\
\text { in the country }\end{array}$ \\
\hline Soto (2000) & $\begin{array}{c}\text { Forty four } \\
\text { developing } \\
\text { countries }\end{array}$ & 1986-1997 & $\begin{array}{l}\text { Generalized Method } \\
\text { of Moments } \\
\text { (GMM) }\end{array}$ & $\begin{array}{l}\text { Foreign direct investment (FDI) } \\
\text { and portfolio investment (PI) } \\
\text { has a positive and significant } \\
\text { relationship with economic } \\
\text { growth. }\end{array}$ \\
\hline Akinlo (2004) & Nigeria & $1970-2001$ & $\begin{array}{c}\text { Error Correction } \\
\text { Model (ECM) }\end{array}$ & $\begin{array}{l}\text { Foreign direct investment might } \\
\text { not be growth enhancing }\end{array}$ \\
\hline $\begin{array}{c}\text { Ekwe \& Inyiama } \\
\text { (2014) }\end{array}$ & Nigeria & $1982-2012$ & OLS & $\begin{array}{l}\text { Foreign capital inflow had a } \\
\text { significant and positive effect } \\
\text { on economic growth. }\end{array}$ \\
\hline Sethi (2013) & India & $1995-2011$ & $\begin{array}{l}\text { Pairwise Granger } \\
\text { causality test }\end{array}$ & $\begin{array}{l}\text { Economic growth Granger } \\
\text { causes FDI and PI }\end{array}$ \\
\hline $\begin{array}{l}\text { Ajayi \& Oke } \\
\quad(2013)\end{array}$ & Nigeria & & OLS & $\begin{array}{l}\text { High level of debt led to the } \\
\text { devaluation of the country } \\
\text { currency. }\end{array}$ \\
\hline Ali (2014) & Pakistan & $1972-2013$ & $\begin{array}{l}\text { Pairwise Granger } \\
\text { causality test }\end{array}$ & $\begin{array}{c}\text { The result revealed a negative } \\
\text { effect of capital inflow on } \\
\text { economic growth in the long- } \\
\text { run }\end{array}$ \\
\hline $\begin{array}{l}\text { Osnubi \& } \\
\text { Amaghionyodiw } \\
\text { e }(2010)\end{array}$ & Nigeria & $1970-2005$ & ECM & $\begin{array}{l}\text { Foreign private investment } \\
\text { enhances growth positively. }\end{array}$ \\
\hline $\begin{array}{l}\text { Odhiambo } \\
\text { (2011) }\end{array}$ & Tanzania & $1980-2005$ & ARDL & $\begin{array}{l}\text { Causality flowing from foreign } \\
\text { capital inflows to economic } \\
\text { growth. }\end{array}$ \\
\hline $\begin{array}{c}\text { Ayadi \& Ayadi } \\
(2008)\end{array}$ & $\begin{array}{l}\text { Nigeria, South } \\
\text { Africa }\end{array}$ & 1994-2007 & $\begin{array}{l}\text { OLS, Generalized } \\
\text { least square (GLS) }\end{array}$ & $\begin{array}{c}\text { Negative effect of debt on } \\
\text { growth was confirmed in South } \\
\text { Africa and Nigeria. }\end{array}$ \\
\hline $\begin{array}{c}\text { Rajan \& } \\
\text { Subramanian } \\
(2005)\end{array}$ & $\begin{array}{l}\text { Thirty three } \\
\text { developing } \\
\text { countries }\end{array}$ & & OLS & $\begin{array}{l}\text { Aid inflows have a systematic } \\
\text { effect on a country's } \\
\text { competitiveness. }\end{array}$ \\
\hline Sakyi (2011) & Ghana & $1984-1990$ & ARDL & $\begin{array}{l}\text { Foreign aid has a positive } \\
\text { impact on growth. }\end{array}$ \\
\hline
\end{tabular}

Table 4. Summary of Literature 
Ikpesu

Appendix-V
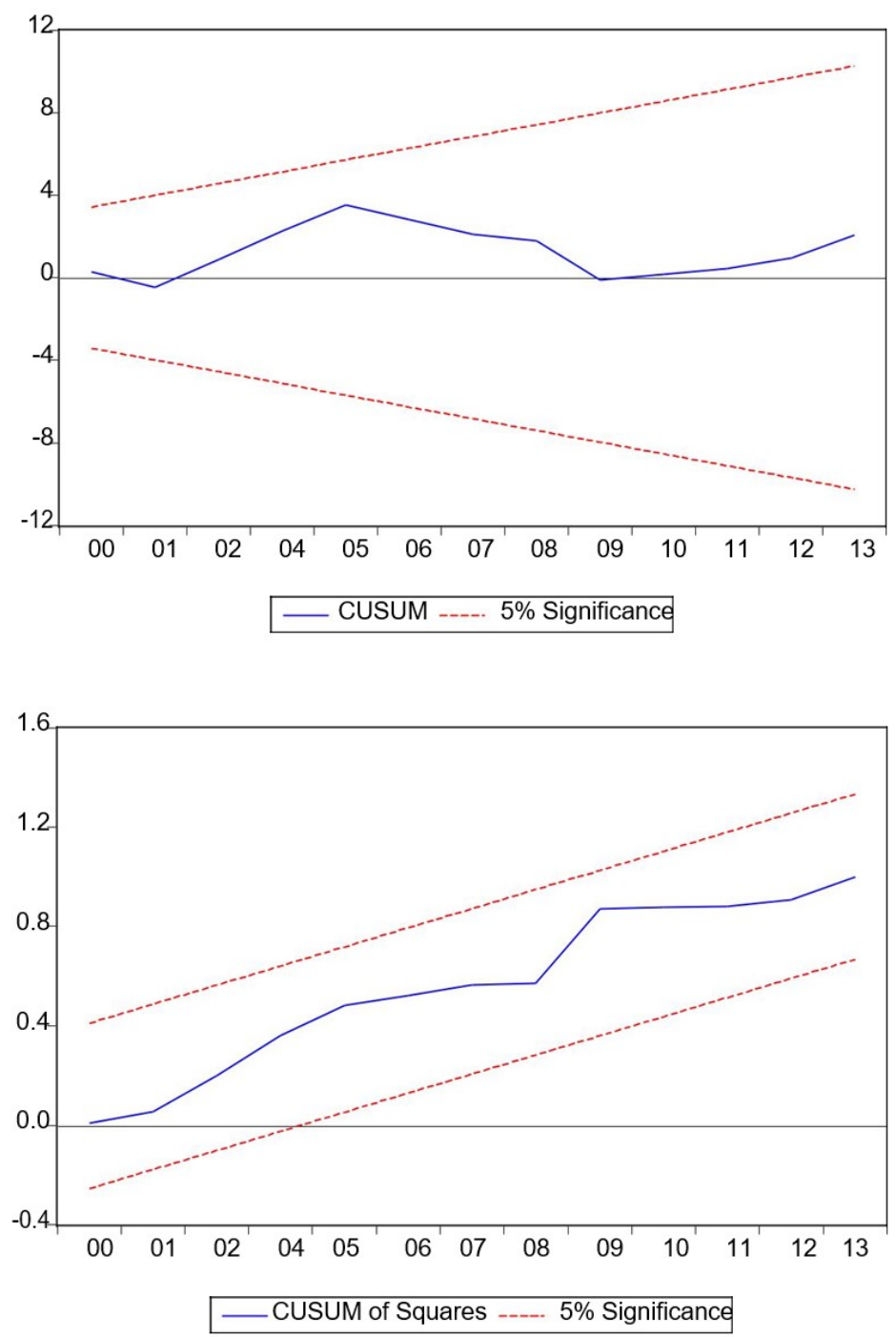

Figure 1. Stability Test 